\title{
THE DEVELOPMENT OF HOUSING SECTOR AND RESIDENTIAL REAL ESTATE MARKET AFTER ECONOMIC RECESSION IN LATVIA
}

\author{
Sanda GEIPELE ${ }^{1}$, Armands AUZIN̦Š ${ }^{2}$ \\ ${ }^{1,2}$ Riga Technical University, Latvia \\ sanda_geipele@inbox.lv \\ armands.auzins@rtu.lv
}

\begin{abstract}
The study is concerned with an examination of resource distribution in order to promote sustainable development of housing sector in the context of evolving residential real estate market after the economic recession period in Latvia. The statistical and comparative analysis methods have mainly been applied in the study, and the recommendations on the implementation of conceptual solutions for promoting the efficient management of housing sector according to the public needs have been provided. The findings of the study may significantly contribute when improving the housing policy and appropriate institutional environment in Latvia.
\end{abstract}

Keywords: Housing sector, real estate, residential market, sustainable development.

\section{INTRODUCTION}

Residential construction is one of the major real estate market segments. The research on its current development is related to transactions with real estate of the housing sector (stock) - individual residential houses (mansions) and high-rise multi-family residential buildings. The development of housing sector indicates the household formation. The research results of the current development are necessary to evaluate the state and potential of the sector, market situation in the relevant time period and development trends.

In general, in the residential construction segment the real estate transaction objects in Latvia can be divided into land with or without buildings, buildings and structures located on land owned by another person (buildings estate), apartments or group of premises. The housing sector is composed of individual houses, prewar multi-family residential buildings, as well as multi-family residential buildings in serial design projects and apartments in new construction projects.

The real estate market is never perfect; there are market failures. The housing sector is aging, if it is not renewed to the extent required. The real estate market can offer real estate taking into account not only the need for provision of housing functions, but also the potential to create a solvent demand by offering highquality dwellings in new and modern development projects. For this purpose, conceptual solutions can be found to increase efficiency measures and to promote the housing sector management in accordance with the public interest. 
The aim of the study is to explore the current state of the housing sector, to analyse the real estate market development trends in the residential construction segment and to assess the potential and opportunities in Latvia as a whole and in its separate regions, where the population concentration is higher and the market is more active. To achieve the aim, the following major tasks are defined: (1) to explore the living area and the dynamics of market transactions of related land units as well as development trends over the last five years; (2) to evaluate the housing sector characteristics in certain research areas; (3) by assessing the structure of housing sector and real estate transaction intensity in the residential construction market segment, to explain the factors that affect housing sector aging and the stagnant nature of real estate market over the last five years; (4) based on the research results and their interpretation (discussion), to draw meaningful conclusions and make proposals for promoting housing sector development projects.

To conduct the research, the methods of statistical and comparative analyses are used to analytically evaluate the dynamic time series by real estate classification as well as the housing sector structure and the real estate market in the residential construction segment. The methods of logical construction and historical analysis are used to analyse the housing sector, to identify the development trends, to choose and evaluate the development projects.

\section{THE STATISTICAL TIME SERIES ANALYSIS AND DISCUSSION OF THE RESULTS}

The research provides the analytical assessment of real estate classification in order to obtain basic information and to reveal the development characteristics, challenges and opportunities of the housing sector of real estate market. The structure of constructions and residential buildings gives an idea of the composition and state of the housing stock. Construction volume variability, building permits issued and residential buildings commissioned in new construction projects provide an overview of new housing supply in the real estate market. Real estate transaction dynamics and market development trends in its certain segments identify the market activity and potential.

The research indicates a number of restrictions and constraints that have affected the context of the research conducted and the interpretation of the results obtained. The research analyses the statistical time series, including the territory of the Republic of Latvia, the territory of Riga and the territory of Pieriga statistical region. Pieriga statistical region includes 17 amalgamated municipalities of former Riga region, which until the changes in the administrative-territorial division in 2009 (Saeima, 2008) were part of the territory of Riga region, as well as another 11 municipalities, which at present are included into the agglomeration of the capital of Latvia - Riga. 


\subsection{The Structure and Development of the Territory and Housing Sector}

General requirements for local spatial development planning, land use and construction in Latvia also include, among others, the types of land use for provision of residential construction functions, envisaging low-rise and high-rise construction territories (MK, 2013). The low-rise buildings shall not exceed three stories, but the high-rise buildings may have four or more stories. In the low-rise residential construction territory (LRC), the primary types of residential buildings are private houses, row houses and multi-family residential buildings up to three stories high. Private residence construction territory (PRC) is intended to provide housing functions for a solitary lifestyle, and it is primary used for the construction of mansions and summerhouses. High-rise residential construction territory (HRC) is mainly used for the construction of multi-family and row houses. All the three functional zones are distinguished to ensure the relevant housing function, providing appropriate infrastructure.

In 2011, by request of the State Regional Development Agency the requirements were designed to improve digital topographic map specifications for spatial planning needs, which envisaged the interrelation of functional zoning classification with the classification of real estate use objectives (REUOs) (VARAM, 2015). The REUO classification (MK, 2006) was developed primarily for the needs of cadastral valuation and real estate tax administration. Thus, establishing the link between the two classifications, the PRC is aimed at land areas for individual residential construction (codes: 0601, 0600), the LRC corresponds to land areas for multi-family residential construction (codes: 0701, 0702, 0700), but the HRC is intended for land areas of multi-family residential construction (codes: 0702, 0703, 0704, 0700).

In order to analyse the land use classification in Latvia, the division by the REUO groups is used, which in the housing sector comprises land areas for individual residential construction (code: 06) and land areas for multi-family residential construction (code: 07). The REUO land units are assigned to local municipalities and registered in the National Real Estate Cadastre Information System (NRECIS), which is maintained by the State Land Service (SLS). Municipalities determine REUOs for all land units and land parts of the unit or planned land units and planned land parts of the unit. REUOs are defined for land units if a new land unit or its part is established, or if there is no use objective determined for an existing land unit (MK, 2006).

The local municipality determines whether it is necessary to set, change or cancel the REUOs, evaluating all available documents and the information on a particular land unit made available from the NRECIS. The next step is to make a request for information in written form from the administrative actors, state and municipal executive bodies. Evaluating the documents received, inspection is carried out, if necessary. On the basis of the information acquired, the municipality determines whether it is really necessary to set the use objective and if it is not necessary to perform, it prepares a draft letter to the citizen and informs the SLS. As a result, the municipality has to carry out many activities in order to legitimately and correctly determine REUOs (Auzins, Geipele and Geipele, 2013). 
The application of efficiency indicators to evaluate the land use efficiency points to the rational assessments and the necessity to support a decision-making process using and restoring land resources in the long term. To ensure a sustainable land management practice, processes associated with land use should be regularly evaluated (Auzins, Geipele and Geipele, 2014).

Assessing the division of land areas for residential construction by the two REUO groups for the period of 2010-2015 in the territory of the Republic of Latvia, the city of Riga and the former territory of Riga region (VZD, 2015a), the statistics of these REUO groups and their dynamic time series indicate that comparing the both types of construction land areas, a higher number of land units and land areas occupied are intended for individual residential construction. It is also concluded that since 2010 relatively insignificant changes in the number of land units and areas have been observed in the research territories, showing the permanence of the housing sector in the provided land areas in general and, thus, by these two characteristics pointing to the invariance of the housing sector development in Latvia.

The registering of buildings as cadastral objects is performed by the SLS according to the Law on National Real Estate Cadastre and the procedures determined by the Cabinet of Ministers. The NRECIS registers all buildings, which have undergone a cadastral survey in accordance with the procedures determined by the Cabinet of Ministers. The buildings are classified according to the Regulations of the Cabinet of Ministers No. 1620 as of December 22, 2009 "Regulations on the Classification of Buildings" (MK, 2009), which determine the classification of buildings by classification objects, structure and major type of use. According to building registration data as on January 1, 2015 in the NRECIS $1,393,789$ constructions were registered, of which $1,367,519$ or $98 \%$ were buildings (non-residential buildings $1,007,622$ or $72 \%$, and residential buildings 359897 or $26 \%$ ) and $2 \%$ or 26,270 - engineering constructions (VZD, 2014a).

It should also be noted that the type of building use is determined in accordance with the type of use specified in the construction project documentation, taking-over certificate or the certificate issued by relevant municipal authority.

According to the Regulations of the Cabinet of Ministers (MK, 2009), in the division of buildings by their major type of use 22 main types of use are distinguished. However, under the provisions of Annex "Classification of Buildings" residential buildings are classified as follows: single-family buildings; two-family or multi-family residential buildings; three-family or multi-family residential buildings and buildings shared for living by various social groups.

Since the analysis is performed on the housing sector development and improvement opportunities, Table 1 demonstrates the data on the division of residential buildings by the major types of use in Latvia at the beginning of 2015.

According to the SLS data, the largest proportion of buildings registered in the NRECIS is "Other buildings, not classified elsewhere", which account for $59.5 \%$, followed by "Single-family buildings" (306,295 or $22.0 \%$ of the total number of registered constructions), and non-residential farm buildings $(84,300$ or $6.1 \%$ ). "Three-family or multi-family buildings" take the fourth place of the total 
number of constructions registered in the system (VZD, 2014a). Likewise the classification of land use by the REUO analysed above, the division of buildings by major types of use may also vary due to the real estate market transactions and processes.

Table 1. The Division of Residential Buildings by Major Type of Use in Latvia as of January 1, 2015 (VZD, 2014 ${ }^{\mathrm{a}}$ )

(Number NRECIS; \% of the total number of constructions)

[Table made by the authors].

\begin{tabular}{|l|c|c|}
\hline \multicolumn{1}{|c|}{ Code and major type of use } & $\begin{array}{c}\text { Number of } \\
\text { buildings } \\
\text { (constructions) } \\
\text { NRECIS }\end{array}$ & $\begin{array}{c}\text { \% of the total } \\
\text { number of } \\
\text { constructions }\end{array}$ \\
\hline 1110 - Single-family buildings & 306,295 & 22.0 \\
\hline 1121 - Two-family buildings & 13,473 & 1.0 \\
\hline 1122 - Three-family or multi-family buildings & 39,459 & 2.8 \\
\hline $\begin{array}{l}1130-\text { Buildings shared for living by various } \\
\text { social groups }\end{array}$ & 670 & 0.1 \\
\hline
\end{tabular}

Before performing the real estate market analysis of the housing sector, it is important to find out the age distribution of the housing stock in Latvia (see Fig. 1).

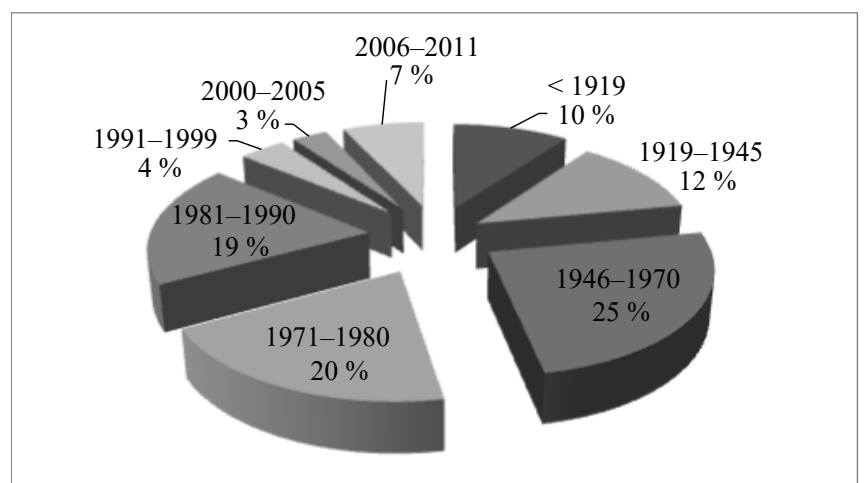

Fig. 1. Age distribution of the housing stock in Latvia, \% (Brick \& Smiles Property Brokers, 2012) [Figure made by the authors].

As shown in Fig. 1, in the period of 1946-1970 the largest number of the residential buildings was constructed, i.e., $25 \%$; it was followed by the period of 1971-1980, during which $20 \%$ of the residential buildings were constructed. The period of 1981-1990 was marked by $19 \%$ of residential buildings constructed. This means that most of the current Latvian housing stock has been built in the period until 1990, in terms of volume making up the most significant part of residential buildings $-86 \%$. Only $10 \%$ of residential buildings were constructed in the period of 2000-2011, which meant that the housing stock in Latvia was changing and developing relatively slowly.

However, according to Riga planning region project "Efficient Energy Building Roadmap for Latvia" concerning the Latvian housing stock structure 
after the period of construction only about $1 \%$ of the Latvian residential buildings have been built since 1993 (RPR, 2012).

According to the SLS data and the previously analysed number of "threefamily or multi-family buildings" in Latvia, at present there are almost 40,000 multi-family residential buildings, which have mainly been built (94\%) until the regaining of independence of Latvia, as demonstrated in Fig. 2.

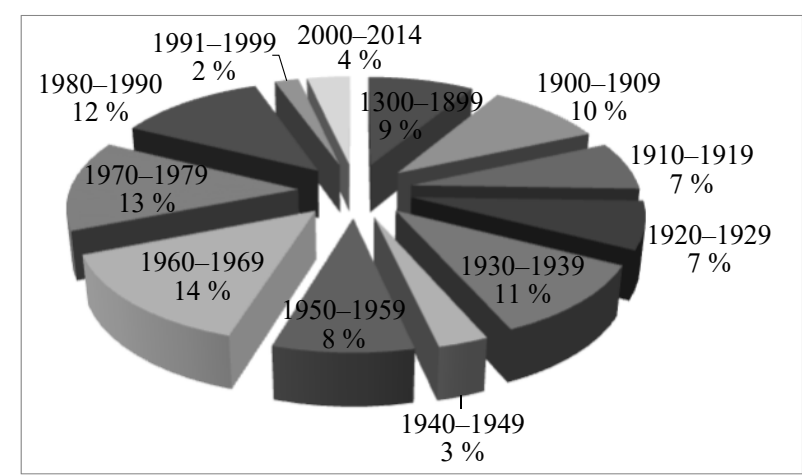

Fig. 2. The proportion of multi-family residential buildings in Latvia (VZD, $2014^{\mathrm{b}}$ ) [Figure made by the authors].

According to the information provided by the SLS, only 2,164 or $6 \%$ of multi-family residential buildings in Latvia were built in the period of 1991-2014, which was a relatively very small number compared to the total number of multifamily residential buildings in Latvia. $94 \%$ or 36,956 of all multi-family residential buildings in Latvia were built in the period of 1300-1990 (VZD, $2014^{\mathrm{b}}$ ).

Collecting and analysing data, it has been concluded that in different information sources the data on the total number of residential buildings in Latvia by the year of construction differ and within the research at present more accurate information is not available to perform the data selection, collection and analysis in a more precise way. However, the information that is available enables one to come to a conclusion that the Latvian housing stock is still developing slowly, and its correct registering and evaluation require general indexing of residential buildings or identification and inspection.

It is also worth mentioning that on the basis of Riga planning region project "Efficient Energy Building Roadmap for Latvia", the existing serial type residential buildings have served for the considerable time period and are no longer considered to be energy efficient according to the evaluated characteristics specified in the project. Designing serial type residential buildings, the main attention was devoted to fast construction time and functionality, provision of many apartments, but the energy consumption by the building, its energy performance were not taken into account (RPR, 2012).

The issues mentioned above allow identifying the necessary contemporary challenges to building renovation or demolition. They should substantiate the implementation and development of housing policy at the national level, as well as assessing the housing potential and recognizing the threats and opportunities related to the housing stock. 


\subsection{Construction Output Changes and Market Supply}

Conducting research on the impact of land-use objectives on the development of Latvian economy (Auzins et al., 2012), the relation of land-use objectives with relevant real estate market segments was substantiated and functional compliance of the relevant objectives with the structure of economic sectors or more precisely - types of sectorial activities - was found. Thus, it has been concluded that in the long term the real estate market is considered to be a function of the economy, but "construction" - a function of other economic sectors, which unlike those sectors characterises supply. Residential construction is associated with the consumption that characterises demand.

To demonstrate the development nature and trends of the housing market, it is important to identify the construction output and the number of newly built apartments that make up the real estate market supply. Within the framework of the present research, following the Central Statistical Bureau (CSB) methodology, the analysis has been performed for the period of 2010-2014 in the Republic of Latvia as a whole as well as in Riga and Pieriga statistical region.

One of the most important macroeconomic indicators of the construction industry - construction product - in the period under analysis indicates significant changes due to internal and external demand, which at the same time are related to the number of newly built apartments. According to the CSB definition, an apartment is a complex of premises envisaged for habitation all year round consisting of one or several rooms and auxiliary premises and having direct exit to street, staircase or common passageway. Auxiliary premises are kitchens, passageways, sanitary facilities, bathrooms, storerooms built-in closets (CSP, $\left.2015^{\text {a }}\right)$.

Figure 3 demonstrates the construction output index at current prices and the number of newly built apartments in Latvia as a whole as well as in Riga and Pieriga statistical region.

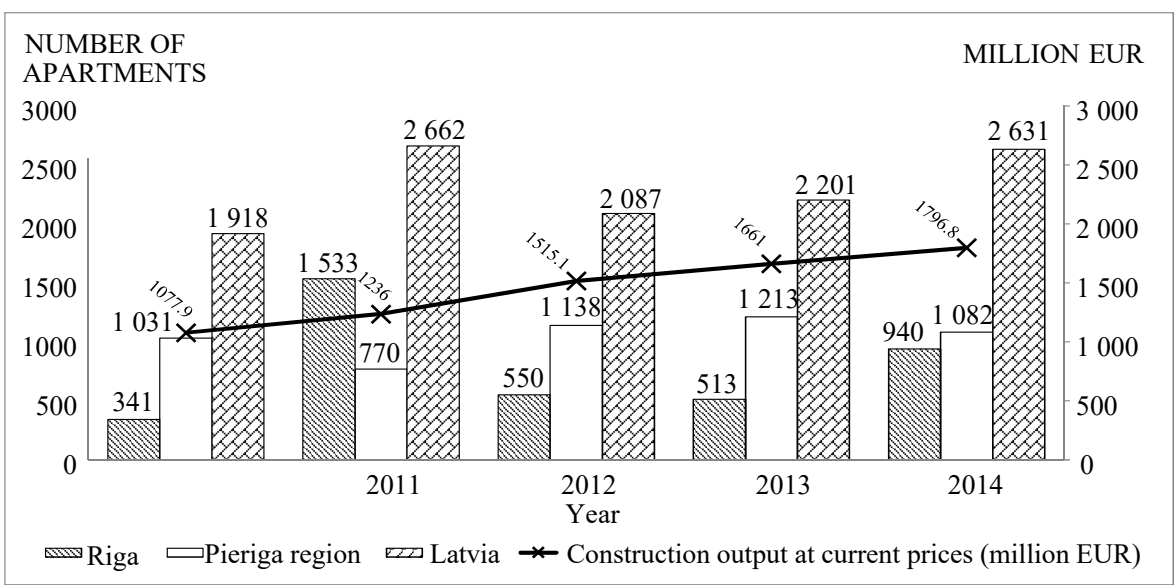

Fig. 3. Construction output changes at current prices and the dynamics of newly built apartments for the period of 2010-2014 (CSP, 2015 ${ }^{\text {bc }}$ )

[Figure made by the authors]. 
After the sharp drop in the period of 2007-2010, when the real estate market experienced downturn, the value of construction output at current prices has started to moderately increase since 2010. A similar trend appears in the analysis of the number of apartments built in the above-mentioned territories in the specified period of time. As Fig. 3 demonstrates, despite the fact that the largest number of apartments built in Latvia and Riga was observed in 2011, the number is still 3.5 times lower in Latvia and 2.63 times lower in Riga compared to that of 2007.

Moreover, it should be emphasised that one of the construction types making up the construction output is new construction and renovation that in 2008 accounted for 351 million EUR at current prices in the residential construction, and in 2013 - 186.7 million EUR at current prices (CSP, 2015 ). By contrast, in 2014 the volume of residential construction increased by $31.1 \%$ compared to that of 2013 (CSP, $2015^{\mathrm{d}}$ ).

According to Fig. 3, Pieriga statistical region is the most active in new residential construction making up $41.13 \%$ of the total number of apartments built in 2014. It should be noted that Riga is not considerably lagging behind in new residential construction $-35.73 \%$ of the total number of apartments built in Latvia. It should also be mentioned that data of Fig. 3 for the period of 2010-2014 do not indicate the rapid development of the real estate market as it has been observed in the upturn period of the Latvian economy - until 2007. It can be stated that the current socio-economic and political situation in Latvia has an impact on the development of real estate market in general, but a more detailed analysis is provided below.

To recognise the development of housing market and its characteristic processes, it is important to determine the number of building permits issued and newly erected residential buildings commissioned. According to the CSB data, residential buildings are divided into single-family buildings (according to the classification of buildings by $\mathrm{CC}$ codes, including the individual residential houses with 1 or 2 apartments) and two-family or multi-family houses (with two and three or several apartments).

Figures 4 and 5 demonstrate the dynamics of building permits issued and newly erected residential buildings commissioned during the period of 2010-2014 in Latvia as a whole as well as in the city of Riga and Pieriga statistical region. Here, it should be noted that the data on the two-family or multi-family buildings commissioned during the research period were not available for the authors of the paper.

In the period of 2010-2014, the number of single-family buildings commissioned exceeded the number of building permits issued for these houses, which could be explained by the reduction in new project construction volume, legalisation of mansion construction, tougher penalties for infringements in cases of non-compliance during the construction process, systematisation of construction rules and regulations and updating construction standards in compliance with legal provisions regulating the quality of building materials and construction products issued by the European Union institutions, a unified and harmonious cooperation between the state and municipal institutions, a higher education level of the population on housing issues after the economic crisis (see Fig. 4). 


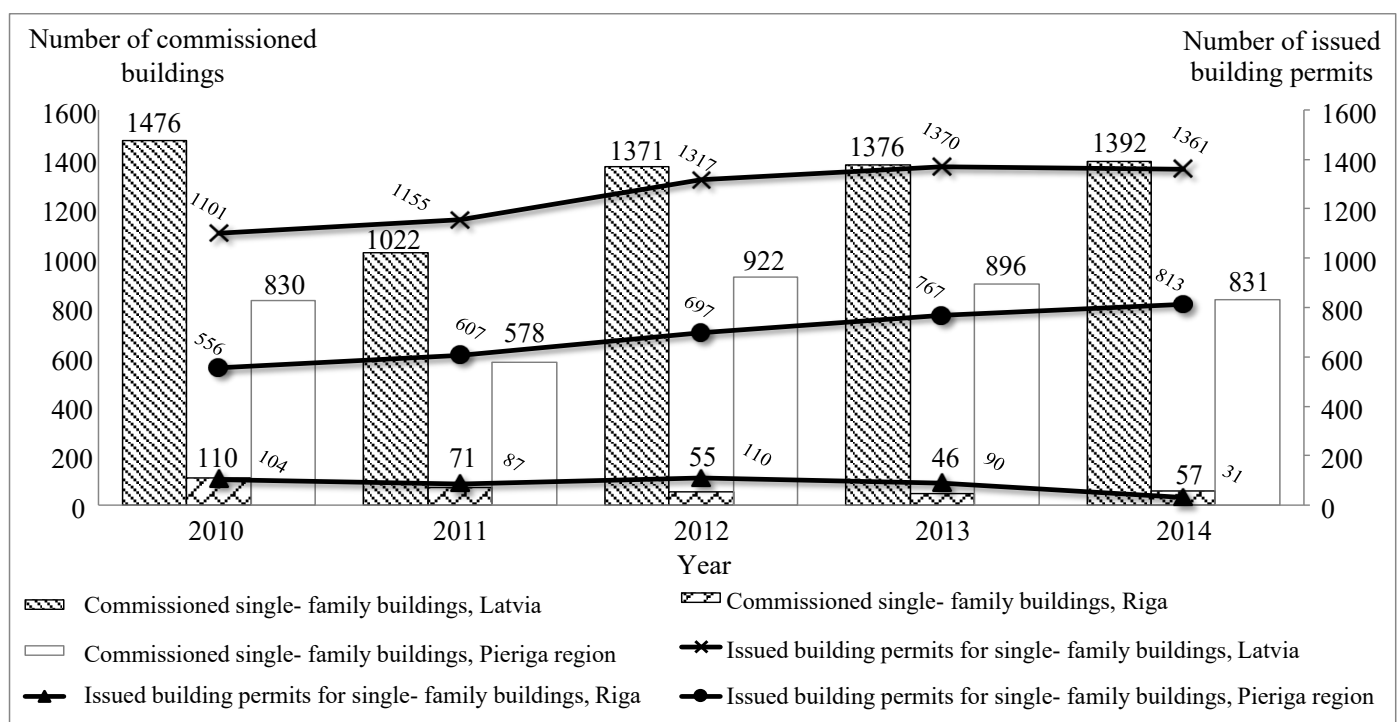

Fig. 4. The number of building permits issued and newly erected residential buildings commissioned during the period of 2010-2014 in Latvia, Riga and Pieriga statistical region (CSP, 2015 ${ }^{\text {ef }}$ ) [Figure made by the authors].

Figure 5 demonstrates the dynamics of building permits issued for newly erected two-family or multi-family buildings in the period of 2010-2014 in Latvia as a whole as well as in the city of Riga and Pieriga statistical region.

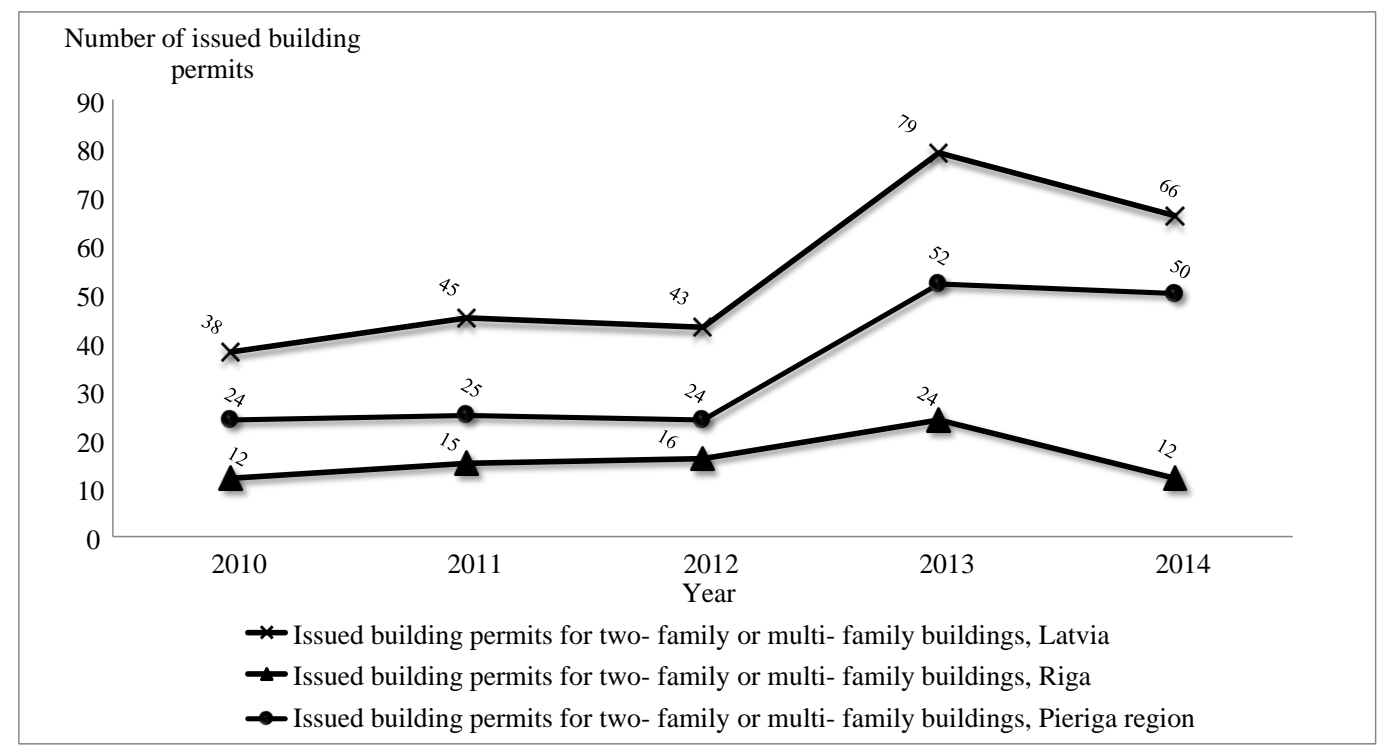

Fig. 5. The number of building permits issued for newly erected two-family or multi-family buildings in the period of 2010-2014 in Latvia as a whole as well as in Riga and Pieriga statistical region $\left(\mathrm{CSP}, 2015^{\mathrm{e}}\right)$

[Figure made by the authors]. 
Likewise the data provided in Fig. 4, the data demonstrated in Fig. 5 indicate that the construction rate of two-family or multi-family buildings significantly decreased at the end of the research period compared to indicators eight years ago when they showed an increase in the number of building permits issued and the buildings commissioned in 2006 and 2007, and at the end of 2007 - a sharp reduction. The studied housing development trends in the period of 2010-2014 suggest that despite the systematisation of the housing stock at the national level, the number of new projects under construction at the end of the research period decreased, which could be explained by socio-economic and legal/political situation in the country. This finding suggests that the national policy should find ways to improve and develop the housing market, especially by means of new project construction due to the aging of residential buildings analysed above.

\subsection{Real Estate Transactions and Market Development}

The real estate market is characterised by information asymmetry, private nature of transactions, and it is affected by a large number of other factors. The real estate market downturn takes place before the economic downturn, but the upturn comes first (Asaul, 2007). Therefore, on the basis of the real estate market development it is possible to evaluate the economic development nature and trends. It is also important to note that in every city the real estate market develops in close contact with rural economic growth. Regions or cities adapt to economic changes as resources between markets are relatively constant. In response to changes in demand, the provision of territory indicators (labour force, capital structure) often occurs very gradually. This creates timely imbalance and promotes the generation of cyclical fluctuations (DiPasquale and Wheaton, 1995).

However, in practice it is not always possible to observe the long-term and stable development; it is related to both the economic development and the real estate market development. Market players would be able to make effective decisions in real estate and construction sectors, if the economic and real estate market development phases, their characteristics, causes and consequences were analysed.

The research involved and analysed the average market value changes and transaction dynamics in the housing market in the city of Riga (the districts, city centre, Old Town), amalgamated municipalities of Riga region and the city of Jurmala in the period of 2010-2014.

The housing market analysis was carried out to identify the changes in the average market value of the apartments in serial type multi-family residential buildings, newly erected residential buildings (with white trim) and reconstructed pre-war houses built before 1940 in Riga (the districts/ city centre/ Old Town), Riga region and Jurmala for the period of 2010-2014, according to aggregated data of real estate company Latio (Latio, 2015). However, the analysis of the transaction dynamics in the housing market was performed on the basis of apartments in serial type multi-family residential buildings and newly erected residential buildings according to the information provided by the State Land Service. 
Riga covers 17 districts of Riga city neighbourhoods. However, in terms of location the city centre combines different construction territories in Riga.

The previously analysed construction output and apartments built, the identified number of building permits issued in the housing sector and newly erected residential buildings commissioned as well as residential construction land areas classified by real estate use objectives represent the situation in the housing market with the average market value changes and the dynamics of transactions (see Figs. 6, 7, 8).

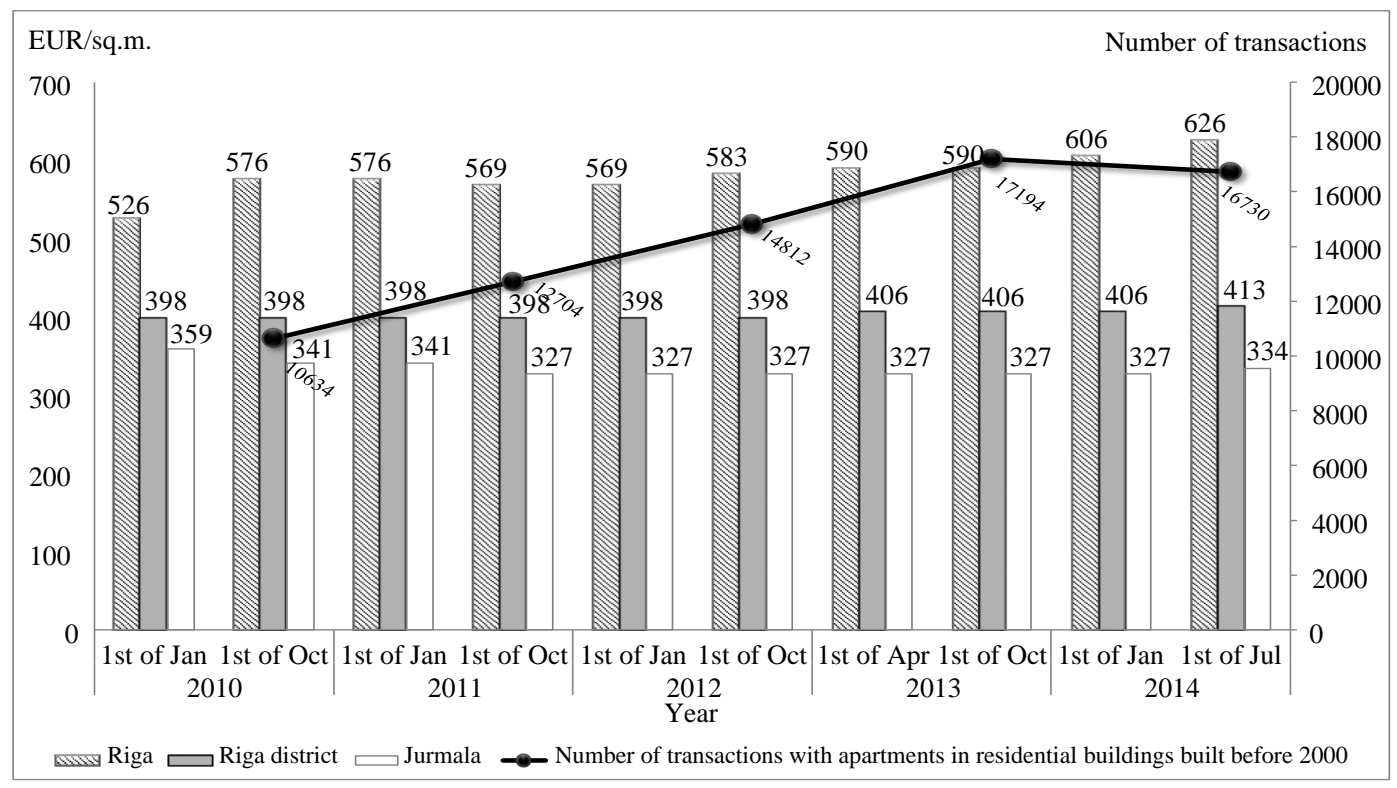

Fig. 6. Average market value of apartments in serial type residential buildings in Riga districts, Riga region and the city of Jurmala according to the data provided by Ltd. Latio (Latio, 2015) and on the basis of the SLS information on the dynamics of transactions with apartments in serial type buildings $\left(\mathrm{VZD}, 2015^{\mathrm{b}}\right.$ ) [Figure made by the authors].

Figure 7 demonstrates the average market value of apartments in newly erected residential buildings in the city of Riga (the districts, city centre and Old Town), Riga region and the city of Jurmala, as well as the transaction dynamics for the period of 2010-2014.

Figure 8 , in turn, demonstrates the average market value of apartments in reconstructed pre-war houses built before 1940 in the centre of Riga and the Old Town for the period of 2010-2014.

As the housing market is usually the most active one, it best reflects the dynamics and intensity of the real estate market transactions. The common characteristic (see Figs. 6, 7, 8) in the data for the period of 2010-2014 indicates the moderate upward trend of Latvian housing market development in 2010 and 2011 , the post-crisis period, which can be explained by the cautious promotion of real estate transaction objects on the market and the conclusion of transactions. 


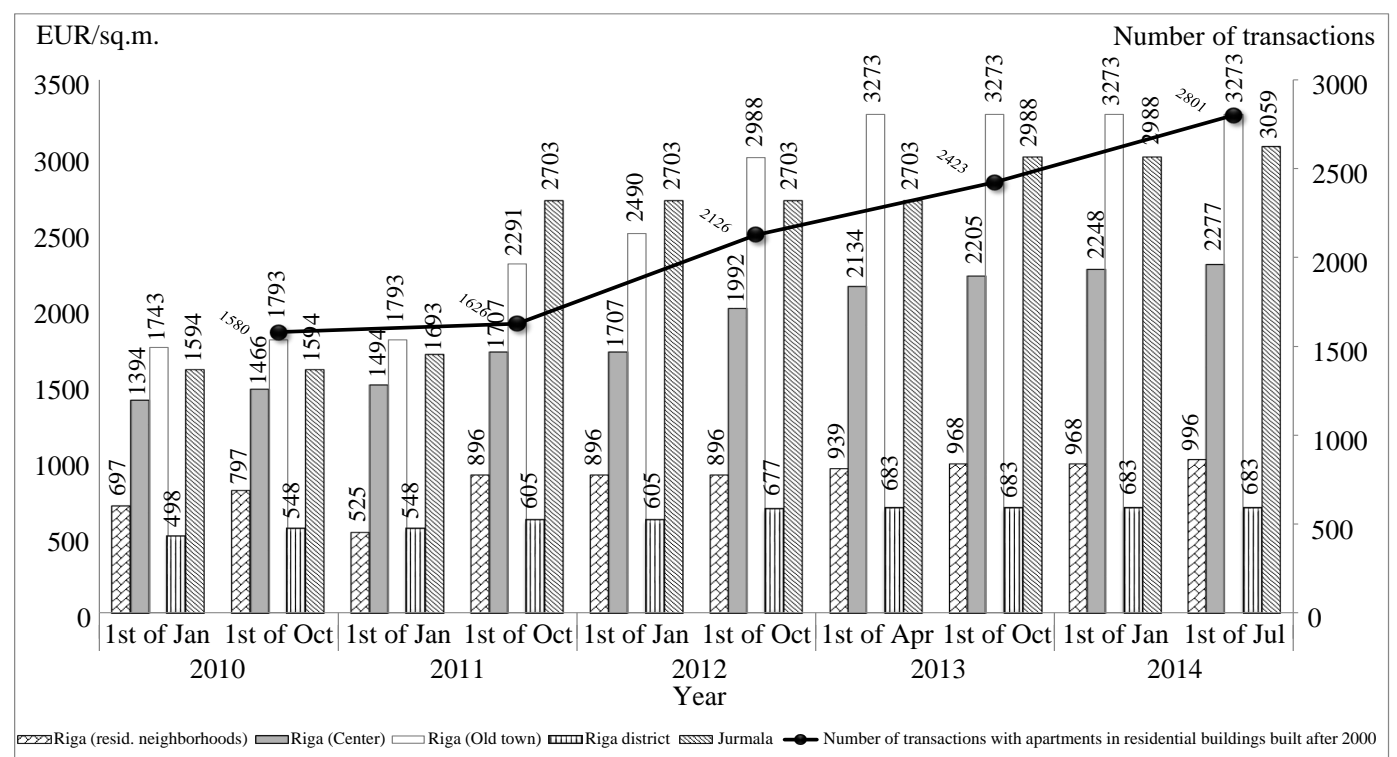

Fig. 7. The average market value of apartments in newly erected residential buildings in the city of Riga (the districts, city centre and Old Town), Riga region and the city of Jurmala according to the data provided by Ltd. Latio (Latio, 2015) and on the basis of the SLS information on the dynamics of transactions with apartments in newly erected residential buildings

(VZD, 2015 ${ }^{\mathrm{b}}$ [Figure made by the authors].

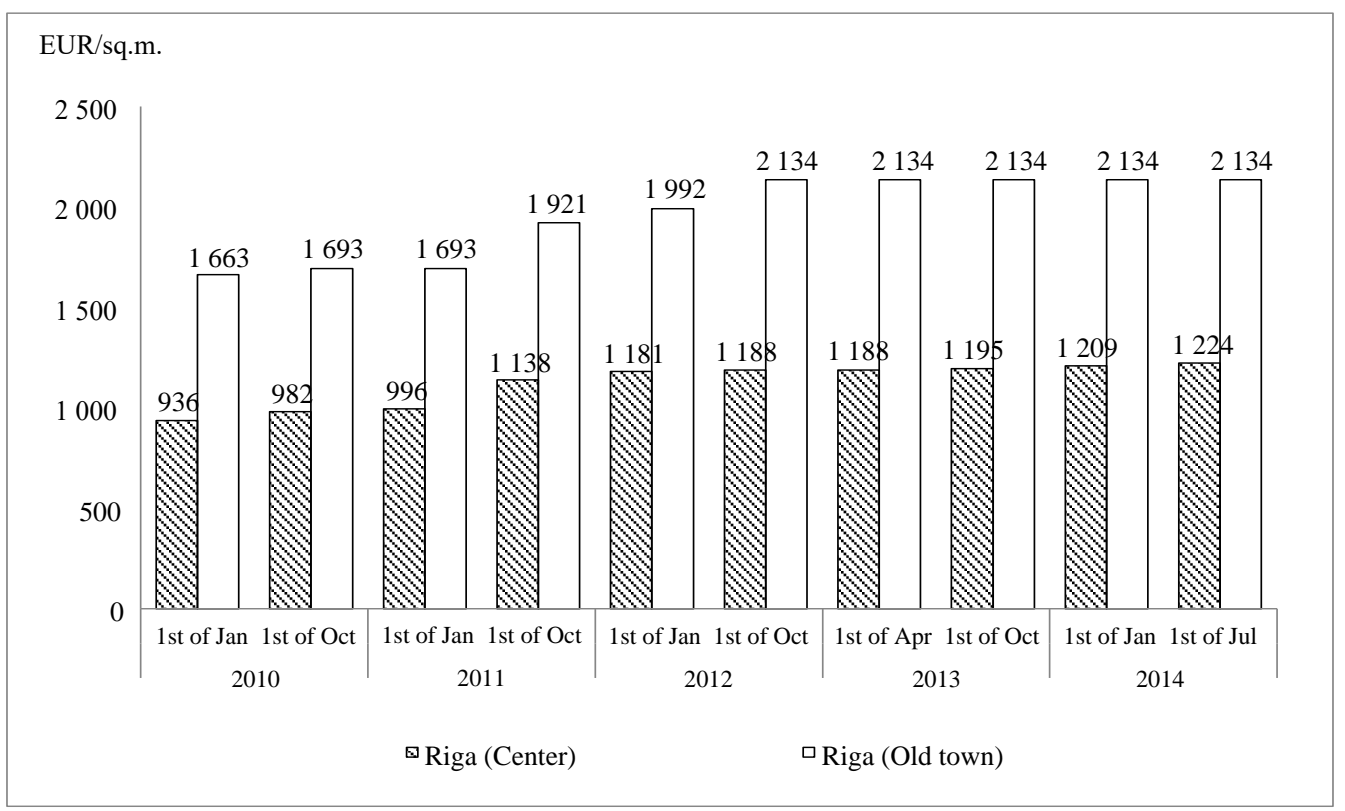

Fig. 8. The average market value of apartments in reconstructed pre-war houses built before 1940 in the centre of Riga and the Old Town according to the data provided by Ltd. Latio (Latio, 2015) [Figure made by the authors]. 
Although since 2011, according to the data provided in Figs. 6, 7, 8, the real estate market has become balanced in terms of average market value and transactions have resumed with apartments in serial type multi-family residential buildings and with apartments in newly erected residential buildings (with white trim), the construction rate of newly erected residential buildings is not as dynamic, despite the Latvian housing sector development and aging. Thus, the future development scenario of housing market depends on the national policy addressing the housing issues, which should envisage drawing up strategic planning documents of housing market development directions and evaluating its effectiveness taking into account socio-economic and legal/ political factors so that a decision-making process in real estate and construction sectors is systemised and effective.

\section{CONCLUSION}

The residential area development in the territory of Riga city is one of the most topical urban environment issues. The main problems are the status of a shrinking city, a relatively small living space per capita compared with other European Union member states, a large proportion of typical residential units in the total housing stock, the depreciation of these buildings, as well as unarranged legislation on property ownership.

Most of the current Latvian housing stock has been built in the period until 1990, in terms of volume making up the most significant part of residential buildings $-90 \%$. Only $10 \%$ of residential buildings were constructed in the period of 2000-2011, which meant that the housing stock in Latvia was changing and developing relatively slowly. According to Riga planning region project "Efficient Energy Building Roadmap for Latvia" concerning the Latvian housing stock structure after the period of construction only about $1 \%$ of the Latvian residential buildings have been built since 1993. However, according to the information provided by the SLS, only 2,164 or $6 \%$ of multi-family residential buildings in Latvia were built in the period of 1991-2014, which was a relatively very small number compared to the total number of multi-family residential buildings in Latvia. $94 \%$ or 36,956 of all multi-family residential buildings in Latvia were built in the period of 1300-1990.

Pieriga statistical region is the most active one in new residential construction, making up $41.13 \%$ of the total number of apartments built in 2014 . It should be noted that statistics of Riga is not considerably lagging behind in new residential construction $-35.73 \%$ of the total number of apartments built in Latvia. The construction output changes at current prices and the dynamics of newly built apartments in the period of 2010-2014 do not indicate the rapid development of the real estate market as it has been observed in the upturn period of the Latvian economy. The socio-economic and legal/ political situation affects the development of real estate market as a whole.

A number of building permits issued and the newly erected residential buildings commissioned demonstrate that the construction rate of residential buildings has significantly decreased at the end of the research period compared to 
indicators eight years ago when they showed an increase in the number of building permits issued and the buildings commissioned in 2006 and 2007, and at the end of 2007 - a sharp reduction. Despite the systematisation of the housing stock at the national level, the number of new projects under construction at the end of the research period has decreased.

The previously analysed construction output and apartments built, the identified number of building permits issued in the housing sector, newly erected residential buildings commissioned as well as residential construction land areas classified by real estate use objectives represent the situation in the housing market with the average market value changes and the dynamics of transactions. This shows that in the past decade a relatively rapid development of the Latvian economy has contributed to the rapid real estate market development and relative stagnation, observing the housing market trends over the last few years.

Since 2011, the Latvian economic situation has become balanced and continues to develop gradually. Thus: (1) real estate market players have become active; (2) credit institutions have resumed mortgage lending, but with much more stringent regulations; (3) the government decisions regarding the temporary residence permits have attracted foreigners' interest and increased the number of transactions in certain real estate market segments; (4) household solvency has also improved gradually.

On the basis of the present research results, it can be stated that taking into account the real estate market development trends in the residential construction segment, the existing housing sector structure and development rate of new residential construction projects in case of the existing institutional environment in housing policy issues, there are limited opportunities to create a solvent demand, providing high-quality dwellings, especially in multi-family buildings. However, the results of the performed analysis at the same time point to the necessity and potential to find socially acceptable conceptual solutions and to increase the efficiency of housing sector management.

\section{SUGGESTIONS}

On the basis of the research conclusions, the following suggestions are put forward, which can contribute to the efficient management and sustainable development of housing sector:

1. Publicly available information on the Latvian residential sector age distribution and its characteristics enables one to conclude that the Latvian housing stock is still developing slowly and its correct registering and evaluation require general indexing of residential buildings or identification and inspection. This would allow for a qualitative assessment of the availability of housing, including new projects that would enable one to identify the occupied and free living space, analyse the reasons why people choose one or the other offer to create their own households.

2. New residential construction is directly related to the well-considered planning solutions of municipality territories and the chosen implementation tools, as well as the substantiation of local infrastructure development (roads, railway 
stations, bus stations, bus stops, waste storage and disposal, playgrounds, green areas, parking lots etc.) for public infrastructure elements.

3. It is necessary to combine a procedural and systemic approach to the real estate market development management, where from the systemic approach perspective management is improvement of the system, i.e., its creation according to the complex evaluation of the identified problems of real estate market development and management system development. Moreover, the process approach determines the functioning of management system parts of all real estate market players in the business development in compliance with the laws and regulations.

4. The Ministry of Economics shall develop planning documents for the real estate market development trends, as well as documents for its effectiveness evaluation, for example, at the national or local level. Developing any object of real estate or performing other activities, feedback has to be received from citizens of a particular region to determine the level of public satisfaction regarding the effectiveness of improvements and their impact on quality of life and environmental conditions. Thus, for the feasibility analysis the particular criteria should be developed, appropriate sets of indicators defined, as well as relevant index values constantly processed.

5. As often buyers and sellers' awareness on the actual state of property and high-quality solution in the long term is of significance, greater emphasis should be placed on the location of the real estate object and the technical quality of object, the quality of management and maintenance services. Consistent development of the country along with higher standards of living is one of the key factors for the proper development of real estate market.

6. The potential policy issues of the Latvian housing development should envisage the assessment of factors affecting the real estate market development in relation to the functioning of the market, which would allow efficiently using resources and increasing the growth of investments in real estate and construction sectors, thus ensuring the stable socio-economic development of the state or a particular territorial-administrative unit in the long term.

7. The performed analysis, its most significant results and the formulated conclusions substantiate the necessity to continue the study of real estate market development opportunities in several directions, including the creation of highquality housing supply by providing the most suitable land areas and creating the appropriate solvent demand, as well as the assessment of challenges, effects and risks, by attracting foreign capital and foreign investments in real estate development.

\section{REFERENCES}

Saeima (2008). Administratīvo teritoriju un apdzīvoto vietu likums [Law on administrative territories and populated areas]. Retrieved from http://likumi.lv/doc.php?id=185993

MK (2013). Vispārīgie teritorijas plānošanas, izmantošanas un apbūves noteikumi [General regulations for the planning, use and building of the territory]. Cabinet of Ministers of the Republic of Latvia. Regulations No. 240. Retrieved from http://likumi.lv/doc.php?id=256866 
VARAM (2015). Prasības elektronisko karšu izstrādei teritorijas plānošanas vajadzībām [Requirements on designing digital maps for spatial planning needs]. Retrieved from http://www.varam.gov.lv/lat/publ/met/met_tap/?doc=15120

MK (2006). Nekustamā īpašuma lietošanas mērḳu klasifikācija un nekustamā īpašuma lietošanas mērķu noteikšanas un maiņas kārtība [Classification of objectives of real property use and determination and change order of objectives of real property use]. Cabinet of Ministers of the Republic of Latvia. Regulations No. 496. Retrieved from http://likumi.lv/doc.php?id=139503

Auzins, A., Geipele, S., Geipele, I. (2013). Set of Fiscal Algorithms for Land-Use Management and Decision-Making in the Territory of a Municipality. In C. A. Long, N. E. Mastorakis, V. Mladenov. (Ed.), Recent Advances in Applied Mathematics and Computational Methods in Engineering. Proceedings of the 2013 International Conference on Applied Mathematics and Computational Methods in Engineering (AMCME 2013). Mathematics and Computers in Science and Engineering Series. Vol. 15. (pp. 296-302). Rhodes Island, Greece. July 16-19, 2013.

Auziņš, A., Geipele, S., Geipele, I. (2014). New indicator system for evaluation of land use efficiency. Industrial Engineering and Operations Management. Proceedings of the 4th International Conference on Industrial Engineering and Operations Management (IEOM). (pp. 2285-2293), Bali, Indonesia, January 7-9, 2014.

VZD $\left(2015^{\mathrm{a}}\right)$. Latvijas Republikas administratīvo teritoriju un teritoriālo vienību zemes pārskati [Overviews of the administrative territories and territorial units of the Republic of Latvia]. State Land Service of Latvia. Retrieved from http://www.vzd.gov.lv/lv/parskati-un-statistika/ tematiskie-parskati/zemes-parskati/

VZD $\left(2014^{a}\right)$. Latvijas Republikas būvju gada pārskats 2014 [Annual report of buildings of the Republic of Latvia 2014]. State Land Service of Latvia. Retrieved from http://vzd.gov.lv/files/ buvju_parskats_2014.pdf

MK (2009). Noteikumi par būvju klasifikāciju [Regulations on classification of buildings]. Cabinet of Ministers of the Republic of Latvia. Regulations No. 1620. Retrieved from http://likumi.lv/ doc.php?id=202919

Brick\&Smiles Property Brokers (2012). Pārdošanas tirgus pārskats 05.10.2012. [Overview of sales market 05.10.2012]. Retrieved from http://www.bands.lv/userfiles/files/B\&S_p $\%$ C4\%81rdo\% C5\%A1anas\%20tirgus\%20p\%C4\%81rskats_05102012.pdf

RPR (2012). Esošās situācijas analīze. Būvniecībā strādājošo kvalifikācijas un prasmju paaugstināšana 2020. gada enerǵijas un klimata mērḳu sasniegšanai [Analysis of current situation. Improvement of qualification and skills of employed in construction for meeting energy and climate objectives of 2020. Project: Efficient Energy Building Roadmap for Latvia. Intelligent Energy - Europe (IEE) Programme. Riga Planning Region. Retrieved from http://www.rpr.gov.lv/uploads/filedir/Status_Quo_Latvija_LV.pdf

VZD $\left(2014^{b}\right)$. Pārskats par kadastrālās vêrtēšanas modeḷa pilnveidošanu daudzfunkcionālām èkām, 2014. gads [Overview of the improvement of cadastral evaluation model for multifunctional buildings, 2014]. State Land Service of Latvia. Retrieved from http://kadastralavertiba.lv/wpcontent/uploads/2015/02/Jaunie_projekti_PARSKATS_2014.pdf

Auzins, A. Grinbergs, M. Geipele, I. (2012). Influence of Development of Land Use Goals to the Economics of Latvia. Proceedings of 2nd International Conference on Applied Social Science (ICASS 2012). - Kuala Lumpur, Malaysia. ISBN 978-1-61275-006-4, Information Engineering Research Institute, USA. - pp. 238-243.

CSP $\left(2015^{\mathrm{a}}\right)$. Uzbūvētās jaunās dzīvojamās ēkas un dzīvokḷi, definīcijas [New-built residential buildings and apartments, definitions]. Central Statistical Bureau of Latvia. Retrieved from http://www.csb.gov.lv/statistikas-temas/metodologija/uzbuvetas-jaunas-dzivojamas-ekas-undzivokli-36992.html

CSP $\left(2015^{b}\right)$. Būvniecības produkcija pa ceturkšņiem [Conctruction products quarterly]. Central Statistical Bureau of Latvia. Retrieved from http://data.csb.gov.lv/pxweb/lv/rupnbuvn/ rupnbuvn_isterm_buvn/BU0010c_euro.px/table/tableViewLayout1/?rxid=562c2205-ba574130-b63a-6991f49ab6fe 
CSP $\left(2015^{c}\right)$. Uzbūvēto dzīvokḷu skaits statistiskajos reǵionos, republikas pilsētās un rajonos [Number of built apartments in statistical regions, cities and districts]. Central Statistical Bureau of Latvia. Retrieved from http://data.csb.gov.lv/pxweb/lv/rupnbuvn/rupnbuvn_ikgad _majokli/MA0050.px/table/tableViewLayout1/?rxid=562c2205-ba57-4130-b63a-6991f49ab6fe

CSP $\left(2015^{\mathrm{d}}\right)$. Būvniecība [Construction]. Central Statistical Bureau of Latvia. Retrieved from http://www.csb.gov.lv/sites/default/files/skoleniem/sekundarais_sektors/buvnieciba.pdf

CSP $\left(2015^{\circ}\right)$. Izdoto būvațlauju skaits èku būvniecībai statistiskajos reǵionos, republikas pilsētās un novados [Number of issued building permits in statistical regions, cities and district]. Central Statistical Bureau of Latvia. Retrieved from http://data.csb.gov.lv/pxweb/lv/rupnbuvn/ rupnbuvn_ikgad_majokli/MA0055.px/table/tableViewLayout1/?rxid=562c2205-ba57-4130b63a-6991f49ab6fe

CSP $\left(2015^{f}\right)$. Ekspluatācijā pieņemto jaunuzbūvēto viena dzīvokḷa māju skaits statistiskajos reǵionos, republikas pilsētās un novados [Number of new-built family houses put into operation]. Central Statistical Bureau of Latvia. Retrieved from http://data.csb.gov.lv/pxweb/ lv/rupnbuvn/rupnbuvn_ikgad_majokli/MA0056.px/table/tableViewLayout1/?rxid=562c2205 -ba57-4130-b63a-6991f49ab6fe

Asaul, A. N. (2007). Экономика недвижимости. 2-е изд. [Real Property Economics, 2nd ed.]. СПб.: Питер, p. 624.

DiPasquale, D., Wheaton, W. (1995). Urban Economics and Real Estate Markets. - USA: Prentice-Hall Inc, p. 378.

Latio (2015). Study of Latio market analysis unit, Riga: Latio.

VZD $\left(2015^{\text {b }}\right)$. Statistika par tirgus darījumiem [Statistics on real property transactions]. State Land Service of Latvia. Retrieved from http://www.vzd.gov.lv/lv/parskati-un-statistika/statistika/ statistika-par-tirgus-darijumiem/

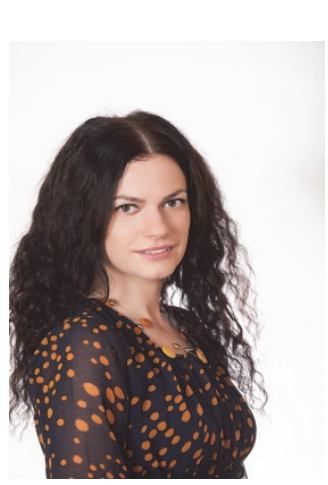

\section{AUTHORS' SHORT BIOGRAPHY}

Sanda Geipele, Dr. oec, Assist. Prof., Researcher, Riga Technical University, Latvia. Within over 5 years she worked as a Chief Economist at Riga City Council's Municipal Revenue Department and her work was related with real estate tax administration. Research interests: sustainability development problems of real estate market, construction industry, including land use management and institutional economics. She is the author and co-author of 32 scientific publications. Since 2010 she has participated in more than 16 scientific conferences and 5 international scientific and practical projects. Sanda Geipele is an expert in management and economic sciences of the Latvian Council of Science.

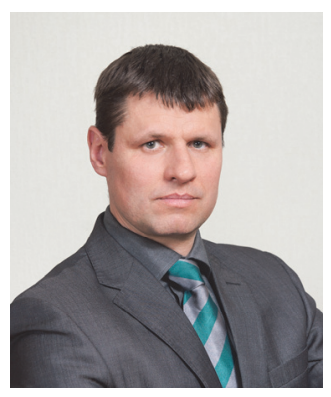

Armands Auziņš, Dr. oec., Assoc. Prof., Riga Technical University, Latvia. He is a scientific expert in management and economic sciences of the Latvian Council of Science. He is a member of the European Academy of Land Use and Development and a board member of the Latvian Association of Land Surveyors (FIG member). Dr. oec. Auziņ̌s has more than 15 years of consulting experience in land use management. $\mathrm{He}$ is lecturing in land management field and has published 27 scientific conference papers as well as participated in international research projects. His research interests include land use management, institutional and real estate economics, and land use evaluation techniques. 